\title{
NEW DATA ON ACOUSTIC SIGNALS OF STAURODERUS SCALARIS (ORTHOPTERA: ACRIDIDAE) FROM DIFFERENT LOCAL POPULATIONS WITH A NOTE ABOUT ITS PARASITE FROM THE GENUS BLAESOXIPHA (DIPTERA: SARCOPHAGIDAE)
}

\author{
Alexander A. Benediktov*, Oleg A. Belyaev** \\ Lomonosov Moscow State University, Russia \\ e-mail:*entomology@yandex.ru,**olegent@yandex.ru
}

Received: 17.08.2018. Revised: 19.09.2018. Accepted: 25.10.2018.

\begin{abstract}
Calling acoustic signals of Stauroderus scalaris males are described for the first time, the oscillograms from Samarskaya Luka and the Republic of Tuva are published. Comparative analysis of parameters of calling signals of this species from different discrete populations (Western Europe, South Kazakhstan, Kyrgyzstan, and Russia) was carried out. High degree of acoustic conservatism of sound signals of the dark-winged grasshopper is shown for the entire area. Moreover, a parasite fly of orthopteran insects, Blaesoxipha redempta, is reported for the first time on the territory of Samarskaya Luka (Zhiguli State Nature Biosphere Reserve, Bakhilova Polyana settlement). It is the first find of a representative of the genus Blaesoxipha in the reserve, emerged from a S. scalaris male specimen. Photographs of genital apparatus of the male fly specimen are given; it is well distinguished from closely related species by the shape of cerci and phallus. Possible infection strategy of the parasitic fly concerning acoustically active orthopteran hosts is discussed.
\end{abstract}

Key words: acoustic conservatism, calling signals, dark-winged grasshopper, first record, invasion strategy, orthopteran insects, parasitic flies, Samarskaya Luka, Tuva

\section{Introduction}

The dark-winged grasshopper, Stauroderus scalaris (Fischer von Waldheim, 1846) (Fig. 1) is an important element of acridocoenoses because males have loud, sharp and rather long-term acoustic signals. It inhabits the Palearctic region from Europe to the Transbaikal area. Its populations are also known in forest-steppe zones and in the southern taiga, in the northern steppe zone, in the mountains of Southern Siberia, in the Tian-Shan, in the Northern Pamirs, in the Caucasus Mountains, and in Elbrus. Sergeev (2014) noted that local populations of this species are more or less separated from each other. Apparently they are isolated from each other so that many species populations simply disappeared, while the remained appeared to be discretely located. Because of this, information about acoustic signals of Stauroderus scalaris from various local populations is interesting for systematics and zoogeography. However, until now only a few oscillograms and descriptions of the males' calling signals have been published from Western Europe, Southern Kazakhstan, Kyrgyzstan and Russia (Republic of North Ossetia, Republic of Altai, Republic of Buryatia, Saratov region, and Irkutsk region) (Ragge \& Reynolds, 1998; Vedenina \& Bukhvalova, 2001; Tishechkin \& Bukhvalova, 2009; Tishechkin, 2017).
It should be particularly noted that Stauroderus scalaris has status of a serious crop pest. At sharp population growth, it can cause damage in European Russia, Caucasus, Siberia, Northern and Eastern Kazakhstan, the mountains of Kyrgyzstan, and in some countries of Western and Eastern Europe (Mishschenko, 1972). In this regard, information on the biology of this species and its interrelations with other insects (in particular with parasitic flies, which are natural regulators of insect abundance) from different areas is relevant.

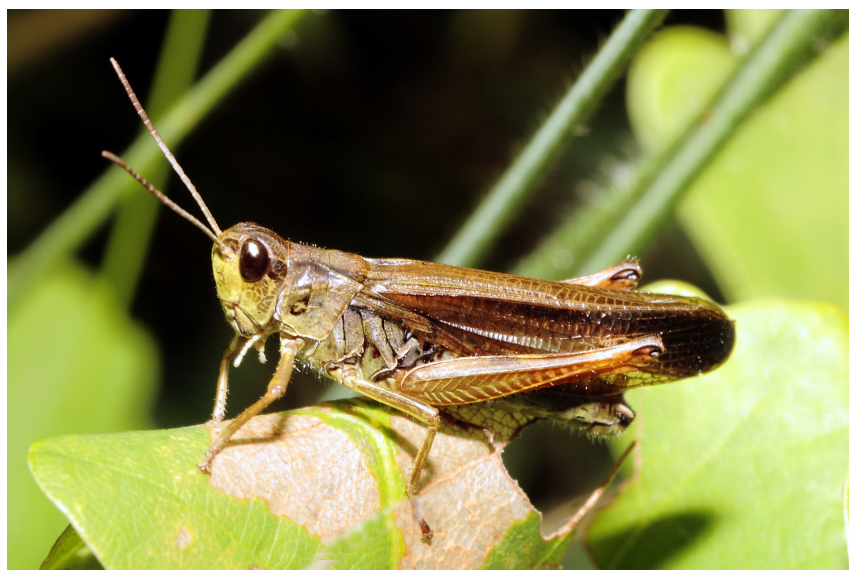

Fig. 1. Male Stauroderus scalaris from Bakhilova Polyana settlement (Samara region, Russia). Photo: A.A. Benediktov. 
Concerning a parasite-host relationship, we should say that some parasitic flies from families Sarcophagidae and Tachinidae are able to find acoustically active insects by their sound signals (Leonide, 1969; Lehmann, 2003; Hedwig \& Robert, 2014; Tron et al., 2016). This interesting fact was confirmed by using sound traps in nature as well, when parasites were caught by playback of acoustic signals of their hosts, in particular crickets (Orthoptera: Gryllidae) (Cade, 1975) and mole crickets (Orthoptera: Gryllotalpidae) (Fowler, 1987). Observation of the fly Emblemasoma auditrix (Soper et al., 1976) is even more interesting. It is the parasite of Cicadidae (Homoptera) (Soper et al., 1976). It reacts to sound signals of male hosts; as a result, most of the infected individuals are males. After infestation, males lose the ability to further emission of sounds, that makes them inaccessible to other parasites and prevents multiple parasitism. Analyses of responses of auditory afferents and interneurons show that the tympanal organ of $E$. auditrix is broadly tuned, with a sensitivity peak at $5 \mathrm{kHz}$ (Tron et al., 2016.). Single-cell recordings of auditory interneurons indicated a frequencyand intensity-dependent tuning, whereby some neurons react best to $9 \mathrm{kHz}$, the peak frequency of the host's calling signal. Because of this, knowledge about acoustic signals of host-insects becomes even more actual.

In July 2016, the first author caught three Stauroderus scalaris males from the Zhiguli State Nature Biosphere Reserve (settlement Bakhilova Polyana) and delivered them to Moscow for bioacoustic studies. The insects were put into a closed insectarium with three-months-old soil. Two days later one insect suddenly died and a week later a young parasitic fly occurred in the terrarium. The study showed that it was Blaesoxipha redempta (Pandelle, 1896) (Diptera: Sarcophagidae). This species was not known in Samarskaya Luka before; moreover it is not included in the Cadastre of invertebrates of Samarskaya Luka (Rozenberg, 2007). According to the report of I.V. Lyubvina (entomologist of the Zhiguli State Nature Reserve), this fact is very interesting, because there are seven species of the genus Blaesoxipha Loew, 1861 in the Reserve's collection, but all of them are known from the south of Samara region, not from the territory of the Zhiguli Reserve.

Below, we present for the first time the descriptions and oscillograms of acoustic signals of Stauroderus scalaris from Samara region (Samar- skaya Luka of the Zhiguli State Nature Reserve, Bakhilova Polyana) and the Republic of Tuva (Kyzyl). They were compared with the descriptions published previously. Also, we give detailed information on the parasitic fly Blaesoxipha redempta which is hosted by this grasshopper.

\section{Material and Methods}

On 23 July 2016 a record of acoustic signals was made in the settlement Bakhilova Polyana at a temperature of $+27-30^{\circ} \mathrm{C}$ (A. Benediktov) on a grass meadow along the road between the office and the cemetery. According to acoustic signals, the number of these grasshoppers was not high: within hearing distance, five males per 1 $\mathrm{h}$ were determined by acoustic signals, three of them were collected. For comparison, we used author's records of the same species from the Republic of Altai (a male, outskirts of the village Chemal, grazed meadow, temperature near $+30^{\circ} \mathrm{C}$, A. Benediktov) and the Republic of Tuva (a male, vicinity of the town Kyzyl, wormwood steppe, temperature $+30-33^{\circ} \mathrm{C}$, A. Benediktov). Acoustic signals were recorded by a mini-recorder Sony Hi-MD Walkman MZ-RH910 (20-20000 $\mathrm{Hz})$ with microphone MIC-01 (40-16000 Hz) (Bakhilova Polyana) or by cassette tape recorders «Electronics-302» (63-10000 Hz) (Altai) and Proton-402 (40-12500 Hz) with microphone MKE-9 (50-15000 Hz) (Tuva). Further processing and analysis of oscillograms were carried out using a computer. The traditional terminology was used to describe signals: a signal (phrase) consists of echemes, each of them is formed by syllables (Zhantiev, 1981).

\section{Results and Discussion}

Stauroderus scalaris (Fischer von Waldheim, 1846)

Acoustic signals. Males produce prolonged loud echeme-sequence (Fig. 2) from 11 to $25 \mathrm{~s}$. in length. It is completely consistent with data of other authors who registered signals of $10 \mathrm{~s}$. up to 30 s. (Vedenina \& Bukhvalova, 2001; Tishechkin $\&$ Bukhvalova, 2009). A male usually produces the discrete loud echeme-sequence right after landing. Sitting for a long time, prior to the loud echemesequence, a male can protractedly stridulate discrete echemes of syllables with unstable intervals (up to 1.5-2.0 min.), emitting the so-called «introduction» (Ragge \& Reynolds, 1998). According to these characteristics, no differences among all the males studied were revealed. 


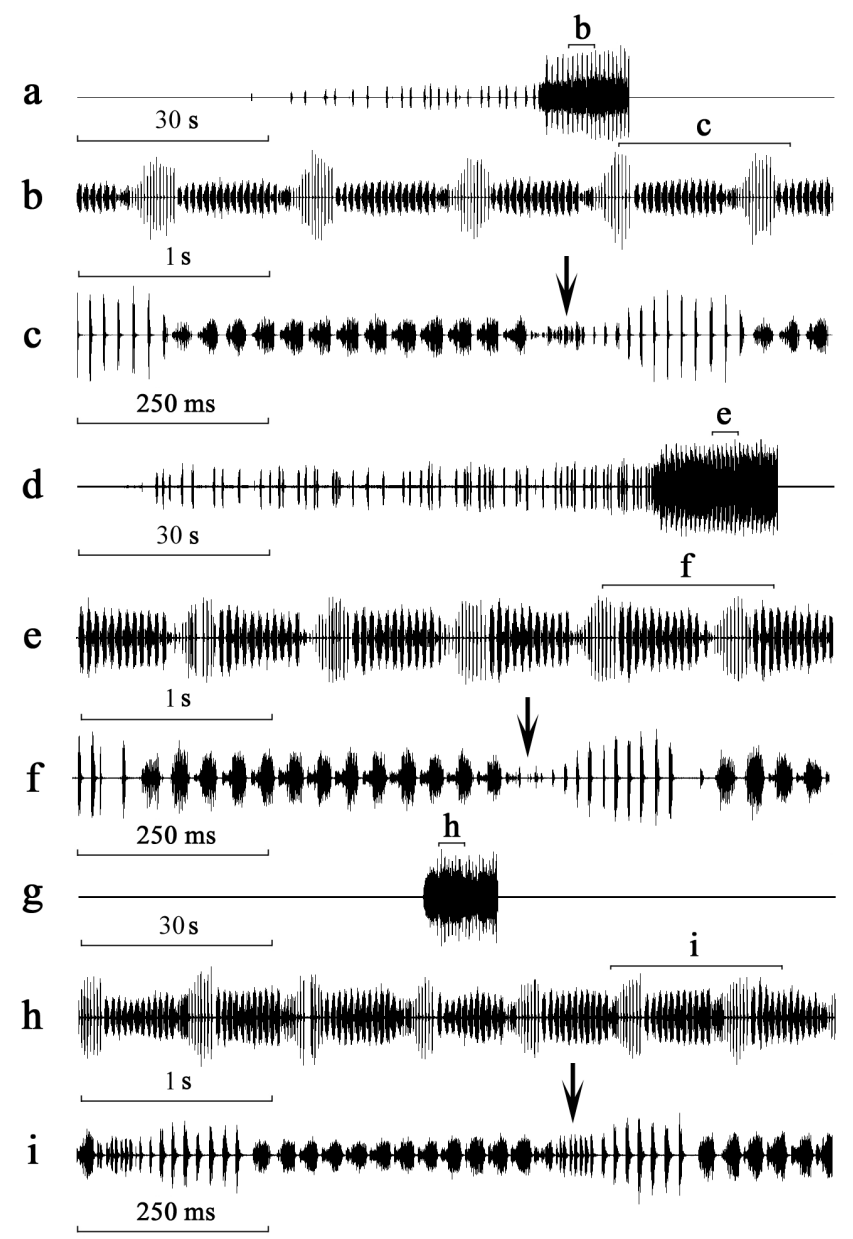

Fig. 2. Oscillograms of calling signals of males of Stauroderus scalaris from different regions: Samarskaya Luka (Bakhilova Polyana) (a-c), Republic of Altai (Chemal) (d-f), Republic of Tuva (Kyzyl) (g-i) at different sweep speed. Arrows show transition phases.
The echeme repetition period in loud echemesequence is the most important for acoustic identification of a sexual partner in grasshoppers as well as the number of syllables per echeme (Table 1). Loud echeme-sequence of the calling signal of Stauroderus scalaris consists of numerous echemes. Each of them consists of two parts, formed by long and short syllables. However, at large sweep speed, it is clear that there is one more transition phase between these parts where syllables follow with shorter (in contrast to the second part) intervals and occasionally they are poorly distinguishable (Fig. 2, shown by arrows). Also, this phase can not be referred to longer syllables, because at the same sweep speed their internal structure is completely indistinguishable, unlike the transition phase. This phase is the result of a change of the algorithm of leg movement during stridulation (Elsner \& Popov, 1978) from low to high amplitudes. It should be noted that during the calculation of number of long and short syllables, the transition phase can not always be accounted.

The obtained results (Table 1) show that main characteristics of acoustic signals of the males from Samarskaya Luka and the Republic of Tuva fit into their variation range from different locations. Noteworthy, that repetition period of echemes and number of syllables in them vary, decreasing from the beginning to the end of a loud echeme-sequence (Table 2). Hence, a male begins to stridulate faster with shorter echemes. This feature is observed for calling signals of $S$. scalaris from all the locations studied.

Table 1. Characteristics of acoustic calling signals of males of Stauroderus scalaris

\begin{tabular}{|c|c|c|c|c|}
\hline Region & Temperature, ${ }^{\circ} \mathrm{C}$ & $\begin{array}{c}\text { Echeme repetition } \\
\text { period, s. }\end{array}$ & $\begin{array}{c}\text { Number of syllables } \\
\text { in the } 1^{\text {st }} \text { part of an } \\
\text { echeme }\end{array}$ & $\begin{array}{c}\text { Number of syllables } \\
\text { in the } 2^{\text {nd }} \text { part of an } \\
\text { echeme }\end{array}$ \\
\hline $\begin{array}{c}\text { Russia, Samarskaya Luka } \\
\text { (Bakhilova Polyana) }\end{array}$ & $+27-30$ & $\begin{array}{c}709.79 \pm 74.61 \\
\mathrm{n}=33\end{array}$ & $\begin{array}{c}11.97 \pm 2.37 \\
\mathrm{n}=35\end{array}$ & $\begin{array}{c}10.46 \pm 1.27 \\
\mathrm{n}=35\end{array}$ \\
\hline Russia, Republic of Altai (Chemal) & +30 & $\begin{array}{c}696.38 \pm 42.62 \\
\mathrm{n}=50\end{array}$ & $\begin{array}{c}11.10 \pm 1.23 \\
\mathrm{n}=50\end{array}$ & $\begin{array}{c}9.90 \pm 1.14 \\
\mathrm{n}=51\end{array}$ \\
\hline Russia, Republic of Tuva (Kyzyl) & $+30-33$ & $\begin{array}{c}555.05 \pm 22.68 \\
\mathrm{n}=19\end{array}$ & $\begin{array}{c}10.79 \pm 0.98 \\
\mathrm{n}=19\end{array}$ & $7.70 \pm 1.03$ \\
$\mathrm{n}=20$
\end{tabular}

Note: mean values $\pm \mathrm{sd}$ are given ( $\mathrm{n}-$ number of measurements).

1 - according to Tishechkin \& Bukhvalova (2009);

2 - according to Vedenina \& Bukhvalova (2001);

3 - according to Tishechkin (2017);

${ }^{4}$ - according to Ragge \& Reynolds (1998). 
Table 2. Variation (decrease of values) in characteristics at the beginning and the end of acoustic calling signals of males of Stauroderus scalaris

\begin{tabular}{|c|c|c|c|c|c|c|}
\hline \multirow[t]{2}{*}{ Region } & \multicolumn{2}{|c|}{ Echeme repetition period, ms. } & \multicolumn{2}{|c|}{$\begin{array}{c}\text { Number of longer syllables } \\
\text { per echeme }\end{array}$} & \multicolumn{2}{|c|}{$\begin{array}{l}\text { Number of short syllables } \\
\text { per echeme }\end{array}$} \\
\hline & beginning & end & beginning & end & beginning & end \\
\hline $\begin{array}{c}\text { Russia, Samarskaya Luka } \\
\text { (Bakhilova Polyana) }\end{array}$ & $890-812$ & $632-588$ & $16-15$ & $8-7$ & $14-12$ & $11-9$ \\
\hline $\begin{array}{l}\text { Russia, Republic of Altai } \\
\text { (Chemal) }\end{array}$ & $814-761$ & $625-620$ & $13-12$ & $10-9$ & $13-11$ & $10-8$ \\
\hline $\begin{array}{c}\text { Russia, Republic of Tuva } \\
\text { (Kyzyl) }\end{array}$ & $605-587$ & $533-532$ & $13-12$ & $10-9$ & $11-9$ & $8-7$ \\
\hline
\end{tabular}

Although populations of $S$. scalaris have a discrete distribution within its area (Sergeev, 2014), calling signals of males are more or less similar and overlap by the characteristics studied according to literature. Thus, we can talk about quite high acoustic conservatism of the species throughout the whole area. However, in our opinion, it is worth to pay attention to the differences between intermediate phases in echemes. The problem is that most publications are based on studies of calling signals of 1-2 males from each location. It does not allow us to draw any conclusions in regard to this characteristic at the present stage. It is also possible that this is just some individual variability.

Since acoustic calling signals in grasshopper communities differ by amplitude-time characteristics (Bukhvalova \& Zhantiev, 1993), little attention is paid to studies of the frequency spectrum. It is known that the frequency spectrum is broadband and occupies most part of the audio range, including ultrasound area. In all studied males of $S$. scalaris the main frequency maximum lied in the range $6-14 \mathrm{kHz}$.

Blaesoxipha redempta (Pandelle, 1896)

Taxonomy. The taxonomy of Blaesoxipha species is quite confusing. In regards of the valid name of the emerged fly, we follow the position of Eastern European dipterologists (Povolný \& Verves, 1997; Verves \& Khrokalo, 2006), and note that Blaesoxipha redempta has the following synonyms: $B$. agrestis auct. nec (Robineau-Desvoidy, 1863), B. lineata auct. nec Fallen, 1817 and B. lapidosa Pape, 1994. Thomas Pape has identified our specimen under the last of the above listed names. In order to avoid an error in the species interpretation, below we provide data on the species with indication of its valid name and synonyms, which were used for this taxon in cited publications.

Body morphology. Characters of the male studied (Fig. 3a) are consistent with data pub- lished in the articles (Pape (1987): B. agrestis (Robineau-Desvoidy, 1863) (=B. lineata auct.); Povolný \& Verves (1997); B. redempta (B. agrestis auct, nec Robineau-Desvoidy, 1863, and $B$. lineata auct. nec Fallen, 1817)). They were also confirmed on the base of our photographs (pers. comm. T. Pape: B. lapidosa).

Morphological description. Thorax and abdomen in grey powder with three longitudinal black bands. Dorsal midline black band on thorax extends past the scutellum, three pairs of dorsocentral chaeta $(\mathrm{dc})$ - past the suture. Legs black. Wings with small costal spine, transparent, slightly brownish at the base. Cell $r_{4+5}\left(p_{1}\right)$ is open. Head with a black matte frontal band. Cheeks and clypeus in silvery powder. Palpi and antennae black. Arista long-haired. Body length $7 \mathrm{~mm}$.

Genitalia morphology. We prepared and studied the genitalia specimen (Fig. 3b,c), which were identical to those in descriptions and illustrations published earlier (Pape (1987): B. agrestis $(=B$. lineata); Povolný \& Verves (1997): B. redempta $(=B$. agrestis; $B$. lineata); Peris et al. (2001): B. lapidosa; Verves \& Khrokalo (2006): B. redempta (= B. agrestis, $B$. lapidosa, $B$. lineata); Pekbey \& Hayat (2013): B. lapidosa). In addition they were confirmed on the base of our photographs (pers. comm T. Pape: B. lapidosa). According to Pape (1994), this species can be easily recognised by male genitalia or more precisely by the form of cerci and phallus.

Description of male genitalia. Cerci sickleshaped, gradually tapering towards the end. Surstyli rounded at the apex with elongated basal part. The apical part of paraphallus bent and bifurcated at the end. Aedeagus apodeme elongated.

Distribution. Blaesoxipha redempta is a common species in Palearctic and Ethiopian regions (Rognes (1986): B. agrestis; Pape (1996): B. lapido$s a)$. It is distributed in southern and central regions of European Russia, South Siberia, Amur Region and Primorsky Krai (Verves \& Khrokalo, 2006). 

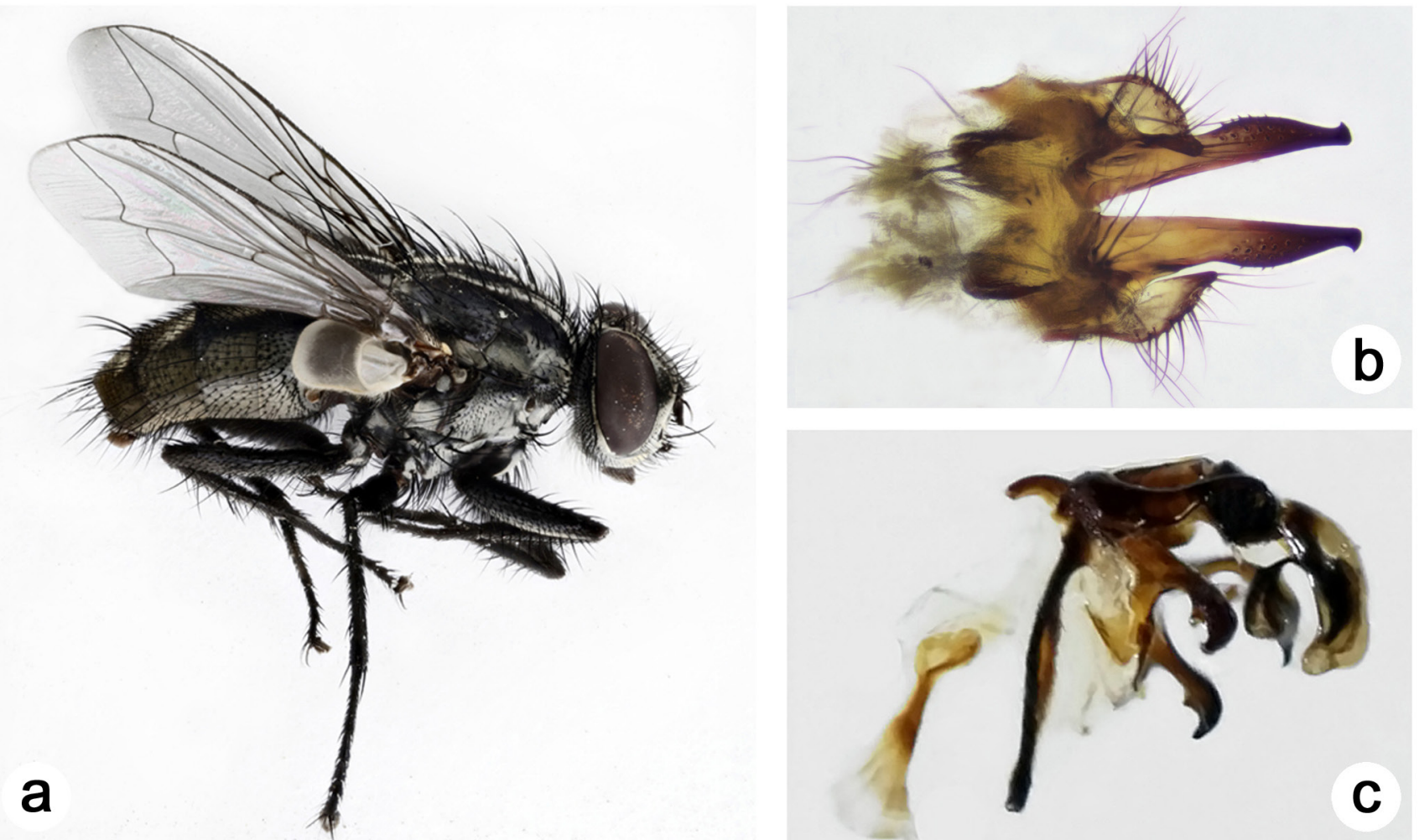

Fig. 3. Male Blaesoxipha redempta (a) and its genitalia: b - cerci and surstyli, c - phallosoma and ejaculatory apodeme. Photo: O.A. Belyaev.

Closely related species. More recently, Blaesoxipha plumicornis (Zetterstedt, 1859), which is closely related to the species studied, has been incubated from a grasshopper Tettigonia caudata (Charpentier, 1845) collected in the Raifa forestry of the Volzhsko-Kamsky State Natural Biosphere Reserve (Karmazina \& Shulaev, 2014). This location is $30 \mathrm{~km}$ west from Kazan city and about $280 \mathrm{~km}$ north from our study area. It is noteworthy that $B$. lineata refers to its synonyms. But it differs from $B$. redempta $(=B$. lineata auct. nec Fallen) by the male genitalia, in particular narrower cerci (Verves \& Khrokalo, 2006).

\section{Conclusions}

The comparison of calling signal characteristics of males of Stauroderus scalaris from Samara region and the Republic of Tuva with those from other discrete populations (Greece, Italy, France, Southern Kazakhstan, Kyrgyzstan, Russia: Republic of Altai, Republic of Buryatia, Republic of North Ossetia, Saratov region, Irkutsk region) has revealed a high degree of acoustic conservatism: the studied parameters of all acoustic signals are similar and lie within the variation range.

Since males of Stauroderus scalaris were collected exclusively by acoustic signals in nature, we can assert that the grasshopper individual infected by fly's larva was capable to stridulate. In the present study we did not aim to investigate the differences between acoustic signals of infected and uninfected grasshopper individuals because we do not know whether other researchers previously studied infected grasshoppers or not.

The identification of the studied fly as Blaesoxipha redempta (Pandelle, 1896) according to the Russian keys and its definition given by the foreign specialist T. Pape as B. lapidosa Pape, 1994 may be expressed in confirmation of the synonymy revealed earlier (Verves \& Khrokalo, 2006).

According to literature data, Blaesoxipha redempta is a parasite of short-horn (Acrididae) and long-horn grasshoppers (Tettigoniidae) which belong to more than 35 different genera of more than five subfamilies. It is possible that due to taxonomic confusions, part of its hosts were reported erroneously. This idea is supported by the note (Verves \& Khrokalo, 2006) that the females oviposit their larvae on wings of flying hosts. However, the mentioned list includes also wingless and not flying grasshoppers (e.g., Prumna spp. (= Primnoa spp.) and Barbitistes spp.). We do not exclude occasional invasion of representatives of the mentioned genera, first of which, moreover, does not produce loud acoustic signals. But if we take into account that all other above-mentioned orthopterans are capable to fly and, at some point, to produce acoustic emission, we cannot exclude the role of orthopteran's acoustic 
signals in search of them by $B$. redempta for further infection. It can be assumed that such large list of the parasite hosts is connected with its orientation only to sound sources of certain frequency, and not with definition of amplitude-time modulation of acoustic signals. After finding a male by its calling signal, the parasite fly stays nearby and waits for a suitable moment to infect a host. Since the invasion occurs towards flying up insects, we can assume that the parasite probably does not see a motionless host which has a cryptic coloration. Only movements of orthopterans allow parasitic fly to identify its host. This is consistent with data on the properties of insect vision (Mazokhin-Porshnyakov, 1965). Perhaps, it is a chance circumstance, whether Blaesoxipha redempta infects flying up males after stridulation, or invades females, which approach males in response to their calling signals, or infects individuals of another species or genus located nearby. However, Zakhvatkin (1954) noted that flying up males were infected by «B. lineata Fall.» (confused by the author with $B$. redempta) more frequently than females. And this fact can indirectly confirm the acoustic search of hosts-grasshoppers by mentioned parasitic flies.

\section{Acknowledgements}

We are grateful to Yuri P. Krasnobaev (director of the Zhiguli State Nature Biosphere Reserve) for permission to work in the village Bakhilova Polyana, A.Y. Sanarsky (Deputy Director for territory protection) for assistance in organisational issues, I.V. Lyubvina (employee of the Zhiguli State Nature Biosphere Reserve) for scientific consultations on the Diptera fauna of the Samarskaya Luka. Special thanks to John Carr (USA, Massachusetts), Theo Zeegers (Netherlands, Soest), and most notably to Thomas Pape (Danish Natural History Museum, Copenhagen) for help in identification of Blaesoxipha species and search of literature. We are also grateful to Alexander B. Ruchin (Director of the Joint Directorate of the Mordovia State Nature Reserve and National Park «Smolny», Russia) for advice on the manuscript structure. Investigations of A.A. Benediktov were supported by the Russian Scientific Fund (No. 14-50-00029) - field works, by RFBR (№ 1604-00706) - analysis of bioacoustic materials, by R\&D (No. AAAA-A16-116021660095-7) - taxonomic studies. Morphological research was performed by O. A. Belyaev with the support of R\&D (No. AAAA-A16-116021660101-5).

\section{References}

Bukhvalova M.A., Zhantiev R.D. 1993. Acoustic signals in grasshopper communities (Orthoptera, Acrididae, Gomphocerinae). Zoologicheskii Zhurnal 72(9): 47-61. [In Russian]

Cade W. 1975. Acoustically orienting parasitoids: Fly phonotaxis to cricket song. Science 190(4221): 1312-1313. DOI: $10.1126 /$ science. 190.4221 .1312
Elsner N., Popov A. 1978. Neuroethology of acoustic communication. Advances in Insect Physiology 13: 229 335. DOI: $10.1016 / \mathrm{S} 0065-2806(08) 60267-2$

Fowler H.G. 1987. Field confirmation of the phonotaxis of Euphasiopteryx depleta (Diptera: Tachinidae) to calling males of Scapteriscus vicinus (Orthoptera: Gryllotalpidae). Florida Entomologist 70(3): 409-410. DOI: $10.2307 / 3495080$

Hedwig B., Robert D. 2014. Auditory Parasitoid Flies Exploiting Acoustic Communication of Insects. In: B. Hedwig (Ed.): Insect Hearing and Acoustic Communication. Animal Signals and Communication. Vol. 1. Berlin, Heidelberg: Springer. P. 45-63. DOI: 10.1007/9783-642-40462-7 4

Karmazina I.O., Shulaev N.V. 2014. Materials for parasitic fauna of orthopteran insects (Insecta: Orthoptera) in the Central part of the Volga-Kama region. Proceedings of Kazan Branch of Russian Entomological Society 3: 36-42. [In Russian]

Lehmann G.U.C. 2003. Review of Biogeography, Host Range and Evolution of Acoustic Hunting in Ormiini (Insecta, Diptera, Tachinidae), Parasitoids of Night-calling Bushcrickets and Crickets (Insecta, Orthoptera, Ensifera). Zoologischer Anzeiger - A Journal of Comparative Zoology 242(2): 107-120. DOI: 10.1078/0044-5231-00091

Leonide J.C. 1969. Recherches sur la biologie de divers dipteres endoparasites d'Orthopteres. Memoires du Museum National d'histoire Naturelle. Serie A, Zoologie 53: 1-246.

Mazokhin-Porshnyakov G.A. 1965. Vision of insects. Moscow: Nauka. 264 p. [In Russian]

Mishschenko L.L. 1972. Family Acrididae. In: O.L. Kryzhanovsky, E.M. Dentsing (Eds.): Insects and mites - pests of agricultural crops. Leningrad: Nauka. Vol. 1. P. 54115. [In Russian]

Pape T. 1987. The Sarcophagidae (Diptera) of Fennoscandia and Denmark. Fauna Entomologica Scandinavica 19: 1-203.

Pape T. 1994. The world Blaesoxipha Loew, 1861 (Diptera Sarcophagidae). Entomologica Scandinavica 45(Supplement): 1-247.

Pape T. 1996. Catalogue of the Sarcophagidae of the World (Insecta: Diptera). Memoirs on Entomology, International 8: 1-558.

Pekbey G., Hayat R. 2013. New Records and Updated Distributions of Blaesoxipha Loew, 1861 (Diptera: Sarcophagidae) from Turkey. Journal of the Entomological Research Society 15(3): 25-36.

Peris S.V., González Mora D., Mingo E. 2001. Las Blaesoxipha «sensu lato» (Diptera, Sarcophagidae) de la Península Ibérica con alguna cita de las Islas Canarias. Boletin de la Real Sociedad Espanola de Historia Natural, Seccion Biologica 96(3-4): 213-230.

Povolný D., Verves Yu.G. 1997. The flesh-flies of Central Europe (Insecta, Diptera, Sarcophagidae). Spixiana Zeitschrift für Zoologie. Suppl. 24: 1-264.

Ragge D.R., Reynolds W.J. 1998. The songs of the grasshoppers and crickets of Western Europe. London: Harley Books, Colchester, Natural History Museum. 591 p. 
Rognes K. 1986. The Sarcophagidae of Norway (Diptera). Fauna Norvegica. Ser. B 33(1): 1-26.

Rozenberg G.S. (Ed.). 2007. Cadastre of invertebrates of Samarskaya Luka: Tutorial. Samara. 471 p. [In Russian]

Sergeev M.G. 2014. Local migrations of grasshoppers in spatially structured landscapes. I. General pattern and dispersal of Stauroderus scalaris (F.d.W.). Euroasian Entomological Journal 13(5): 451-459. [In Russian]

Soper R., Shewell, G., Tyrrell D. 1976. Colcondamyia auditrix nov. sp. (Diptera: Sarcophagidae), a parasite which is attracted by the mating song of its host, Okanagana rimosa (Homoptera: Cicadidae). Canadian Entomologist 108(1): 61-68. DOI: 10.4039/Ent10861-1

Tishechkin D.Yu. 2017. Contributions to the study of Gomphocerine grasshoppers calling songs (Orthoptera: Acrididae: Gomphocerinae) with notes on taxonomic status and distribution of some forms from Kyrgyzstan. Zootaxa. 4318(3): 531-547. DOI: 10.11646/zootaxa.4318.3.6

Tishechkin D.Yu., Bukhvalova M.A. 2009. New data on calling signals of Gomphocerinae grasshoppers (Orthop- tera: Acrididae) from South Siberia and the Russian Far East. Russian Entomological Journal 18(1): 25-46.

Tron N., Stölting H., Kampschulte M., Martels G., Stumpner A., Lakes-Harlan R. 2016. The Auditory System of the Dipteran Parasitoid Emblemasoma auditrix (Sarcophagidae). Journal of Insect Science 16(1): 90. DOI: 10.1093/jisesa/iew062

Vedenina V.Yu., Bukhvalova M.A. 2001. Contribution to the study of acoustic signals of grasshoppers (Orthoptera: Acrididae: Gomphocerinae) from Russia and adjacent countries. 2. Calling songs of widespread species recorded in different localities. Russian Entomological Journal 10(2): 93-123.

Verves Yu.G., Khrokalo L.A. 2006. Family Sarcophagidae. In: Lera P.A. (Ed.): Key to the insects of Russian Far East. Vol. 6: Diptera and Siphonaptera. Part 4. Vladivostik: Dalnauka. P. 64-178. [In Russian]

Zakhvatkin A.A. 1954. Parasites of locusts of the Angara region. Proceedings of the All-Russian Entomological Society 44: 240-300. [In Russian]

Zhantiev R.D. 1981. Bioacoustics of insects. Moscow: Moscow University Press. 256 p. [In Russian]

\title{
НОВЫЕ ДАННЫЕ ПО АКУСТИЧЕСКИМ СИГНАЛАМ STAURODERUS SCALARIS (ORTHOPTERA: ACRIDIDAE) ИЗ РАЗНЫХ ЛОКАЛЬНЫХ ПОПУЛЯЦИЙ С ЗАМЕТКОЙ О ЕГО ПАРАЗИТЕ ИЗ РОДА ВLAESOXIPНA (DIPTERA: SARCOPHAGIDAE)
}

\author{
А. А. Бенедиктов", О. А. Беляев ${ }^{* *}$ \\ Московский государственный университет имени М.В. Ломоносова, Россия \\ e-mail:*entomology@yandex.ru,**olegent@yandex.ru
}

\begin{abstract}
Впервые описаны призывные акустические сигналы самцов Stauroderus scalaris и опубликованы их осциллограммы из Самарской Луки и Республики Тувы. Проведен сравнительный анализ параметров призывных сигналов этого вида из разных дискретных популяций Западной Европы, Южного Казахстана, Кыргызстана и России. Показан высокий акустический консерватизм звуковых сигналов темнокрылой кобылки на всем протяжении ареала. Также на территории Самарской Луки из поселка Бахилова Поляна (Жигулевский государственный природный биосферный заповедник имени И.И. Спрыгина, Россия) обнаружен паразит прямокрылых насекомых - муха Blaesoxipha redempta, выведенная из самца S. scalaris. Это первая находка представителя рода Blaesoxipha в резервате. Представлены фотографии генитального аппарата самца мухи, который хорошо отличается от близких видов формой церок и фаллуса. Обсуждается возможная стратегия мухи-паразита при заражении акустически активных прямокрылых-хозяев.
\end{abstract}

Ключевые слова: акустический консерватизм, паразитические двукрылые, первая находка, призывные звуки, прямокрылые, Самарская Лука, стратегия инвазии, темнокрылая кобылка, Тува 